\title{
Partnerattiecības un homofobija: tiesiskās problēmas Latvijas Republikā
}

\author{
Lidija Rozentāle \\ ORCID: 0000-0001-5139-4642 \\ Rìgas Stradiña universitāte \\ Lidija.Rozentale@rsu.lv
}

\section{Kopsavilkums}

Šì raksta saturs ir balstīts uz pašas autores sākotnējiem pētījumiem. Pētījumā tika iegūti empīriski pārbaudīti argumenti, ka, ieviešot viendzimuma partnerattiecỉbu likumu, var pasliktināties attieksme pret gejiem un lesbietēm. Lai pārliecinātos par viendzimuma partnerattiecību likuma ieviešanas ilgtermiṇa ietekmi uz homofobiju, ir nepieciešams turpināt pētijumus vairākos virzienos.

Līdz divdesmit pirmā gadsimta sākumam notika pilngadīgo viendzimuma seksuālo darbību dekriminalizācija, kḹūstot tiesību normu, kuru iniciēja Eiropas Savienība, kā arī Eiropas Padome. Tomēr lesbiešu un geju tiesiskajās attiecībās joprojām ir dažas problemātiskas jomas, tostarp viendzimuma pāru atzīšana un viṇu kā vecāku tiesības, dibinot gimeni.

Atslēgvārdi: partnerattiecības, viendzimuma laulība, laulïba, homofobija.

\section{levads}

Latvijas sabiedrībā aizvien biežāk tiek diskutēts par jautājumiem, kas skar partnerattiecības un homofobiju, kā arī geju un lesbiešu tiesības un vietu sabiedrībā. Būtiska loma ir sabiedrības attieksmei pret heteroseksuāliem un homoseksuāliem pāriem - nereti seksuālās orientācijas dēḷ sabiedrība tiek provocēta uz konfliktiem. Satversmes tiesas priekšsēdētāja Sanita Osipova 2020. gada 1. decembrī LTV ziṇu raidījumā "1:1" pauda viedokli par pretrunīgi vērtēto Satversmes tiesas 2020. gada 12. novembra spriedumu lietā Nr. 2019-33-01, uzsverot: "Ar cilvēka cieņas principu nav savienojams uzskats, ka viena cilvēka cieņai varētu būt mazāka vērtība nekā cita cilvēka cieņai. Cilvēka cieņas princips nel̦auj valstij atteikties no pamattiesību nodrošināšanas noteiktai personai vai personu grupai. Sabiedrībā pastāvoši stereotipi nevar kalpot par konstitucionāli attaisnojamu 
pamatu noteiktas personas vai personu grupas pamattiesību liegšanai vai ierobežošanai demokrātiskā tiesiskā valstī” (LTV Ziṇu dienests, 2020). Minētais liecina, ka sabiedrībā ir jāpievērš uzmanība cilvēka cienai, lai arī kādai personu grupai viṇš piederētu.

Kā norādīts Apvienoto Nāciju Organizācijas Vispārējās cilvēktiesību deklarācijas 1. pantā, visi cilvēki piedzimst brīvi un vienlīdzīgi cieñā un tiesībās. Viniem ir dots saprāts un sirdsapziña, un viṇiem citam pret citu jāizturas brālības garā. Savukārt deklarācijas 2. pantā ir norādīts, ka katram cilvēkam pienākas visas tiesības un brīīibas, kas pasludinātas šajā deklarācijā neatkarīgi no viṇa rases, ādas krāsas, dzimuma, valodas, reliǵiskās, politiskās vai citas pārliecības, nacionālās vai sociālās izcelsmes, mantiskā stāvokḷa, kārtas vai cita stāvokḷa (ANO Vispārējā cilvēktiesību deklarācija, 1948).

Šiem jautājumiem Latvijā tika pievērsta uzmanība pirms vairāk nekā 20 gadiem. Pētỉjumu "Geju un lezbiešu tiesību stāvokḷa analīze Latvijā" pēc Valsts cilvēktiesību biroja pasūtijuma 1998. un 1999. gadā veica Juris Ludvigs Lavrikovs. Viņš norāda: "Neskatoties uz Latvijas demokrātisko attīstības ceḷu, valstī vēl joprojām pastāv minoritāšu grupas, kas tiek pakḷautas diskriminācijai un neiecietībai ne tikai no pilsoṇu, bet arī no valsts iestāžu puses. Viena no šādām minoritāšu grupām neapšaubāmi ir homoseksuālisti - lesbietes un geji, kuriem ir liegtas arī tiesības būt tikpat vienlīdzīgiem likuma priekšā kā vinu heteroseksuālajiem līdzpilsoṇiem. Šāda situācija neatbilst demokrātiskas valsts idejai un vispāratzìtajām cilvēktiesību normām" (Lavrikovs, 1999). Savukārt Valsts cilvēktiesību biroja pētijumā "Kultūru daudzveidība un iecietība Latvijā. Dati, fakti, viedokḷi" iegūtie dati liecina, ka ir pieaudzis sūdzību un konsultāciju skaits par cilvēktiesību pārkāpumiem. 2001.-2002. gadā ir bijušas 14 rakstiskas konsultācijas par diskrimināciju uz seksuālās orientācijas pamata (Providus, 2003).

Dialogi.lv 2006. gada pavasarī un vasarā īstenoja pētỉjumu "Latvijas iedzīvotāju attieksme pret seksuālajām minoritātēm: dimensijas un "temperatūra"” (Makarovs, 2006). Pētijjumā atklāts, ka attiecībā uz homoseksualitāti Latvijā pastāv divi dominējošie viedokḷu tipi: vairākums iedzīvotāju, no vienas puses, nosoda homoseksuālu dzīvesveidu, bet, no otras puses, ir iecietīgi noskaṇoti pret homoseksuāliem cilvēkiem. Pārsvarā iedzīvotāji izvairās novērtēt kādu cilvēku kā sliktāku viṇas vai viṇa homoseksuālās orientācijas dēll. Iecietība pret homoseksuāliem cilvēkiem ir cieši saistīta ar vecumu - īpaši pozitīvu attieksmi pauž jauni cilvēki vecumā no 15 līdz 24 gadiem (Makarovs, 2006).

Eirobarometra 2019. gada aptaujā konstatēts: lai arī lesbiešu, geju, biseksuālu un transpersonu pieņemšana Latvijā pēdējo četru gadu laikā ir nedaudz uzlabojusies, tā joprojām ievērojami atpaliek no Eiropas Savienības (ES) valstu vidējā līmeṇa. ES valstīs $72 \%$ iedzīvotāju apgalvo, ka nesaskata neko nepareizu viendzimuma attiecībās, savukārt Latvijā - tikai 25\%. Atbalstu viendzimuma laulībām ES valstīs pauž 69\%, savukārt Latvijā - 24\% (Eiropas Parlaments, 2019).

Ekonomiskās sadarbības un attīstības organizācija (Organisation for Economic Co-operation and Development, OECD) 2017. gadā publiskoja datus par attieksmi pret homoseksualitāti organizācijas dalībvalstīs (OECD, 2017). Dati ir daḷa no lielāka pētījuma, kurā aplūkota lesbiešu, geju, biseksuāḷu un transpersonu sociālekonomiskā ieklaušanās 
sabiedrībā. Pēc OECD datiem Latvijas iedzìvotāii noteiktā laika periodā (2001.-2014. gads) pret homoseksualitāti ir attiekušies noraidoši - no 35 dalībvalstīm Latvija atrodas pirmspēdējā vietā. Jaunāki dati šobrīd nav pieejami.

2020. gada 8. novembrī Latvijas sabiedrībā plašu rezonansi izraisīja ziṇa par uzbrukumu Rīgas Stradiṇa universitātes profesoram Denisam Hanovam, kura pamatā, iespējams, bija viṇa seksuālā orientācija un naids pret seksuālo minoritāti. Viens gadījums, protams, nenozīmē, ka sabiedrībā valda neiecietība un negatīva attieksme pret seksuālajām minoritātēm kopumā, bet liecina par diskriminācijas izpausmēm sabiedrībā. Iepriekšminētie pētījumi un 2020. gada 8. novembra uzbrukums apliecina, ka valdība vairāku desmitu gadu periodā nav spējusi rast aizsardzības mehānismu pret seksuālo minoritāšu diskrimināciju. Tas arī aktualizēja jautājumu par šādu nodarījumu veicēju atbildỉbu.

Latvijas iedzīvotāji izmantoja likumdošanas iniciatīvas tiesības, kā to nosaka Latvijas Republikas Satversmes 65. pants, un platformā ManaBalss.lv sāka parakstu vākšanu, lai divi pilngadīgi cilvēki varētu juridiski reǵistrēt (partner)attiecības neatkarīgi no viṇu dzimuma. Ievērojot Latvijas sabiedrības atbalsta trūkuma viendzimuma laulībām / partnerattiecībām, Latvijas Republikas Saeima 2020.gada 29. oktobrī atkārtoti noraidīja 10392 Lat vijas pilsoṇu kolektīvo iesniegumu "Viendzimuma partneru registrēšana". Par iniciatīvas noraidīšanu balsoja 55 deputāti, pret - 30, un viens deputāts atturējās. Pirms gada Saeimas vairākums noraidīja tā dēvēto Dzīvesbiedru likumprojektu, kas cita starpā paredzēja valsts aizsardzību arī viena dzimuma gimenēm.

Raksta mērḳis ir pētìt administratīvās un kriminālatbildības mehānismus par fiziskiem uzbrukumiem un mutiskiem godu un cieņu aizskarošajiem izteikumiem, analizējot pārkāpumus seksuālās orientācijas dẹl, konstatēt tiesību normu nepilnības un piedāvāt iespējamus risinājumus.

Pētījuma metodes: analīiskā metode tika izmantota homofobijas, rasu naida izraisǐšanas un sociālā naida jēdziena, tiesību normu satura izzināšanai, literatūras, kā arī tiesu prakses materiālu izpētei un izzināšanai. Statistiskā pētišanas metode tika izmantota, lai pētîtu statistikas datus par noziedzīgiem nodarījumiem Latvijā, tos analizētu un raksturotu. Deduktīvā metode tika izmantota, lai izdarītu slēdzienus par citu autoru atziṇām un izteiktajiem viedokḷiem. Raksta izstrādes gaitā tika izmantotas arī tiesību normu interpretācijas metodes. Izpētes bāzi veido Latvijā pieejamie pētỉjumi par seksuālajām minoritātēm un iecietību, kā arī dažādu autoru publikācijas un nacionālie tiesību akti.

\section{Diskusija}

Mūsdienās krasi izteiktā homofobija tiek saukta arī par heteroseksismu (rasisma paveidu) vai homoseksuālo paniku. Homofobiju definē gan kā iracionāli negatīvu attieksmi pret homoseksuālistiem, bailēm no saskares ar tiem, kā kognitīvu uzskatu sistēmu un kā aizspriedumu. Ir pamats runāt par homofobiju kā psihopatologiju. Kas tad îsti ir 
homofobija? Vispirms ir jānoskaidro, kas ir homoseksualitāte, lai varētu izprast jēdzienu "homofobija". Par homoseksualitāti tiek uzskatìta seksuāla iekāre, seksuālas darbības un/vai romantiskas attiecības starp viena dzimuma pārstāvjiem. Līdz 1970. gadam homoseksualitāte tika uztverta kā patolog̣ija (Ritter, Terndrup, 2002). Tātad - ārstējama. 1973. gadā Amerikas Psihiatru asociācija svītroja homoseksualitāti no psihisko traucējumu saraksta, jo nevarēja uz to attiecināt medicinā pien,emtos slimības kritērijus. Homoseksualitātes etiologiijas un ārstēšanas pārskatā 1975. gadā tika atzīts, ka psihoanalìtiskās un uzvedības terapijas metodes pieaugušiem cilvēkiem cietušas neveiksmi pat gadījumos, kad pats homoseksuālis apzināti vēlējies mainīt savu seksuālo orientāciju uz heteroseksuālo, bet vēl izskanēja aicinājumi mēǵināt ārstēt zēnus, kuri izrāda sieviššịgas vēlmes, piemēram, geērbties pretējā dzimuma drānās (Acosta, 1975).

Aizspriedumi un naids pret homoseksualitāti rada bailes, kas, pārṇemot indivīdu, kḷūst par cēloni noteiktiem emocionāliem pārdzīvojumiem, kurus sauc par internalizēto homofobiju (Lock, Kleis, 1998). Tie ir arī cēlonis emocionāliem traucējumiem homoseksuāli orientētiem cilvēkiem - to sauc par egodistonisko seksuālo orientāciju (SSK-10 diagnozes kods - F66.1; Williamson, 2000).

Daži psihiatri uzskata, ka izteiktu homofobiju iespējams diagnosticēt - tas ir "neprecizēts seksuāls traucējums kā pastāvīgs un izteikts distress par seksuālo orientāciju", kur distress ir nevis par savu, bet cita cilvēka orientāciju (Woods, Hare, 2010). Tas var būt cēlonis homoseksuālā naida kriminālpārkāpumiem (angl. homosexual hate crime).

Eiropas Parlamenta rezolūcija par homofobiju Eiropā nosaka, ka homofobiju var definēt kā neizprotamas bailes un nepatiku pret homoseksuālismu un homoseksuāliem cilvēkiem - lezbietēm, gejiem, biseksuālām personām un transpersonām (angl. lesbian, gay, bisexual, and transgender, LGBT), tās pamatā ir aizspriedumi, kas ir līdzīgi rasismam, ksenofobijai, antisemìtismam un seksismam (Eiropas Parlamenta rezolūcija par homofobiju Eiropā, 2006). Latvija šai rezolūcijai pievienojās 2006. gadā, uzṇemoties saistības, proti, nodrošināt gan aizsardzību LGBT personām pret homofobiska naida pilniem izteikumiem un vardarbỉbu, gan viena dzimuma partneriem tādu pašu cieṇu un aizsardzību kā pārējai sabiedrības dal̦ai. Homofobiskās izpausmes - seksuālā uzmākšanās, apsaukāšana un uzbrukumi seksuālās orientācijas dēḷ - Latvijā ir, taču aizskartās personas biežāk izvēlas klusēt nekā ziņot tiesībsargājošajām iestādēm. Gan huligānisms Krimināllikumā, gan sīkais huligānisms Administratīvo sodu likumā par pārkāpumiem pārvaldes, sabiedriskās kārtības un valsts valodas lietošanas jomā ir tiesību normas, kas tieši neietver homofobiskus uzbrukumus. Tiesu praksē galvenokārt apskatāmi nolēmumi par atkailināšanos sabiedriskās vietās, alkohola lietošanu, kautiniem, lamāšanos, demolēšanu, šaudīšanos ar gaisa pistoli. Autores ieskatā, būtu nepieciešams pētìt atbildību par homofobiskiem uzbrukumiem un izteikumiem, papildināt un, iespējams, pilnveidot administratīvās atbildības piemērošanu. 


\section{Tiesiskais regulējums - administratīvā atbildība un kriminālatbildība?}

Latvijas sabiedrībā pastāv dažādas domas un viedokḷi par viendzimuma pāriem, tādēl nereti rodas dažādu veidu konflikti, kas izpaužas kā agresija pret homoseksuālām personām un protesta uzvedība. Vispārējā cilvēktiesību deklarācijā, līdzīgi kā Latvijas Republikas Satversmes 116. pantā, ir tiesību norma, kurā paredzēts deklarācijā iekḷauto cilvēktiesību, tostarp tiesību uz vārda brīvību, ierobežošanas mehānisms. Deklarācijas 29. panta otrā daḷa paredz, ka, realizējot savas tiesības un brīvības, katram cilvēkam ir jāpakḷaujas tikai likumā noteiktiem ierobežojumiem, kuru nolūks ir vienīgi citu cilvēku tiesību un brīvību pienācīgas atzīšanas un cieņas nodrošinājums un morāles, sabiedriskās kārtības un vispārējas labklājības taisnīgu prasību apmierināšana demokrātiskā sabiedrībā.

Administratīvo sodu likums paredz atbildību par sīko huligānismu. Šā likuma 11. pants nosaka: "Par sabiedriskās kārtības traucēšanu, pārkāpjot vispārpieṇemtās uzvedības normas un traucējot personu mieru, iestāžu, komersantu vai citu institūciju darbu vai apdraudot savu vai citu personu drošỉbu (sīkais huligānisms), piemēro naudas sodu no četrpadsmit līdz simt naudas soda vienībām." Savukārt Krimināllikuma 231. pants "Huligānisms" paredz atbildību par rupju sabiedriskās kārtības traucēšanu, kas izpaužas acīmredzamā necieṇā pret sabiedrību, ignorējot vispārpieṇemtās uzvedỉbas normas un traucējot cilvēku mieru, iestāžu un uzṇēmumu darbu.

Profesore Valentija Liholaja norāda: "Sabiedriskā kārtība ir tiesību normām un sadzīves noteikumiem atbilstoša kārtība sabiedrībā, kas nodrošina cilvēku mierīgu dzīvi, darbu un atpūtu, iestāžu, uzṇēmumu un organizāciju normālu darbību, citu likumā noteiktu tiesību aizsargāšanu. Savukārt sabiedriskais miers ir viens no sabiedriskās kārtības pamatelementiem" (Liholaja, 2000).

Augstākās tiesas Krimināllietu departamenta 2016. gada 14. jūnija spriedumā pausta šāda atziṇa: "Krimināllikuma 231. pantā ir paredzēta atbildība par rupju sabiedriskās kārtības un sabiedriskā miera traucēšanu, tādēḷ inkriminētā noziedzīga nodarījuma izdarīšana publiskā vietā pati par sevi nenozīmē, ka izdarītais jākvalificē kā huligānisms, ja nevienas citas personas intereses netika aizskartas un rupja sabiedriskā miera traucēšana netika konstatēta. Lai pareizi kvalificētu vainīgās personas nodarījumu, jākonstatē, ka persona tieši vēlējusies izdarìt darbības, kas veido huligānismu kā noziedzīga nodarījuma objektīvo pusi." Tātad, lai sauktu pie atbildības homofobiska uzbrukuma vai seksuālās uzmākšanās gadījumā, jābūt citu personu (sabiedrības) interešu aizskārumam. Ja uzbrukums norisinās bez citu personu (sabiedrības) aizskāruma, tad persona nav saucama pie kriminālatbildības? Analizējot 2020. gada 8. novembra uzbrukumu profesoram Denisam Hanovam, krimināltiesību eksperts Andrejs Judins pauž bažas par uzbrucēja darbību kvalifikāciju, proti, policijai būtu jāskaidro, vai uzbrucēja atkailināšanās ir daḷa no huligānisma vai mēǵinājums izdarīt seksuāla rakstura darbības (Dzērve, 2020). Vienlaikus jānorāda, ka atbildība par seksuālo uzmākšanos bez fiziskas saskares, kāda bija profesora gadījumā, arī nav tieši atrodama Krimināllikumā. 
Krimināllikuma 78. pants ir ietverts IX nodạ̦ā "Noziegumi pret cilvēci, mieru, kara noziegumi, genocīds", kas ir Valsts drošỉbas dienesta institucionālā piekritībā. Savukārt Krimināllikuma 150. pants ir ietverts XIV nodaḷā "Noziedzīgi nodarỉjumi pret personas pamattiesībām un pamatbrīvībām", kas ir Valsts policijas kompetencē (Kamenska, Treḷs, 2017). 2004. gadā, pirms iestāšanās Eiropas Savienībā, Latvija uznēēmās saistības pārṇemt nacionālajos tiesību aktos vairāku ES direktīvu prasības, kas ir saistītas ar diskriminācijas aizliegumu. Viena no tiesību nozarēm, kur bija nepieciešams veikt normatīvo aktu grozījumus, bija krimināltiesības. Tādēl Grozỉjumi Krimināllikumā paredzēja izteikt citā redakcijā Krimināllikuma 78. pantu, nošķirot atbildību par nacionālā un rasu naida vai nesaticības izraisišanu no diskriminācijas aizlieguma. Krimināllikuma 78. pants un 150. pants neaptver visus naida noziegumus. Šo pantu otrā daḷa satur tādu kvalificējošu pazīmi kā "vardarbība" un "draudi", kas tiesu praksē visbiežāk tiek attiecināts uz noziedzīgiem nodarījumiem pret personas veselību. Nacionālā, etniskā un rasu naida izraisǐšanas sastāvs ir atrodams Krimināllikuma Seviškłajā dạ̦ā. Sastāvs atrodams 78. pantā: pirmajā dậa - mazāk smags noziegums, otrajā daḷā - smags noziegums, trešajā daḷā - seviṣ̌̌i smags noziegums. Šajā pantā paredzētais noziedzīgais nodarījums apdraud vienlīdzīgas attieksmes principu personas pamattiesību un pamatbrīvību îstenošanā, personas tiesības uz cienuu, drošỉbu, fizisko un psihologisko neaizskaramību. Pirmā panta daḷa paredz atbildību par darbību, kas vērsta uz nacionālā, etniskā, rasu vai religiskā naida vai nesaticības izraisīšanu. Šādu darbību kriminalizēšanu noteikusi Eiropas Savienības Padome savā pamatlēmumā par krimināltiesību izmantošanu cīṇā pret noteiktiem rasisma un ksenofobijas veidiem un izpausmēm. Krimināllikuma 78. panta pirmā daḷa atbilst šim ES Padomes pamatlēmumam, kura 1. panta pirmā daḷa skan šādi: "Katra dalībvalsts veic vajadzīgos pasākumus, lai nodrošinātu to, ka ir paredzēts sods par šādu tīšu rīcību."

Krimināllikuma 78. panta otrajā dạ̦ā paredzēta atbildība un noziedzīgā nodarỉjuma sastāvs veidojas, ja panta pirmajā dạ̦ā paredzēto noziedzīgo nodarījumu ir izdarījusi personu grupa vai valsts amatpersona, vai uznēemuma (uzṇēmējsabiedrības) vai organizācijas atbildīgs darbinieks vai ja tā izdarīta, izmantojot automatizētu datu apstrādes sistēmu.

Savukārt 78. panta trešajā daḷā noziegums kvalificējams, ja šā panta pirmajā dạ̦ā paredzētā darbība 1) saistìta ar vardarbību vai draudiem vai 2) to izdarījusi organizēta grupa. Noziegums, kas attiecas uz šo Krimināllikuma pantu, ir pabeigts ar darbỉbu, kas vērsta uz nacionālo, etniskā, rasu vai relig̣iskā naida vai nesaticības izraisǐšanu, izdarīšanu - formāls sastāvs (Krastiṇš, Liholaja, 2016).

Tiesu prakse krimināllietās par nacionālā, etniskā un rasu naida izraisīšanu sniegusi vairākas atziṇas, kam varētu būt nozīme, iztiesājot lietu personas apsūdzībā par Krimināllikuma 78. pantā paredzēto noziedzịgo nodarījumu. Augstākās tiesas Krimināllietu departaments 2018. gada 15. jūlija lēmumā Nr. 11840002515, SKK-316/2018 norādījis, ka Krimināllikuma 78. pantā paredzētā noziedzīgā nodarījuma sastāva objektīvo pusi veido darbības, kas vērstas uz nacionālā, etniskā, rasu vai religisiskā naida un 
nesaticības izraisīšanu. Šìs darbības var izpausties ne tikai fiziskā, bet arī verbālā aizskārumā (mutiski un rakstiski), kā arī ir svarīga personas subjektīvā attieksme un motivācija, veicot šādas darbības.

Atškirīīā no fiziskā aizskāruma (vardarbības) verbālais aizskārums (tas var būt izdarīts gan mutvārdos, gan rakstveidā) var aizskart daudz plašāku personu loku. Verbālais aizskārums bieži vien, īpaši angḷu valodā rakstītos pētījumos, tiek saukts par naida runu (hate speech). Eiropas Padomes Ministru komitejas (Council of Europe Committee of Ministers) 1997. gada 30. oktobra Rekomendācijā Nr. (97) 20 sniegts šāds jēdziena "naida runa" skaidrojums: "“Naida runa" pārklāj visas izteiksmes formas, kas izplata, mudina, veicina vai attaisno rasistisku naidu, ksenofobiju, antisemītismu vai citas naida formas, kas balstìtas uz neiecietību, iekḷaujot neiecietību, kas nāk no agresīva nacionālisma, etnocentrisma, diskriminācijas un naida pret minoritātēm, migrantiem un ārvalstu izcelsmes cilvēkiem." No minētā izriet, ka naida runa ir naida noziegumu paveids (Treḷs, 2019). Tiesību zinātṇu doktors Ėriks Treḷs norāda, ka naida noziegumi var izpausties

1) fiziska aizskāruma (vardarbības) veidā;

2) verbāla aizskāruma veidā (mutvārdos un rakstveidā);

3) citā naida izpausmes veidā, piemēram, tî̌̌i iznīcinot un bojājot mantu - izsitot logus, pārdurot automašĩnas riepas u. tml. (Treḷs, 2012).

Jēdzieni "naida noziegumi" un "naida runa" Latvijā nav normatīvi nostiprināti. Klasiskā Austrumeiropas izpratnē jēdziens "naida noziegums" biežāk tiek attiecināts uz nacionālā, etniskā, rasu vai religíiskā naida izraisiš̌anu (Treḷs, 2019).

Šobrīd spēkā esošā Krimināllikuma 150. panta redakcija paredz atbildību par sociālā naida un nesaticības izraisī̌̌anu. Proti, par jebkādu darbību, kas vērsta uz naida vai nesaticības izraisī̌nanu "atkarībā no personas dzimuma, vecuma, invaliditātes vai jebkuru citu pazimju dēl, ja ar to radīts būtisks kaitējums". Panta trešã daḷa paredz pastiprinātu atbildību, ja darbības ir "saistītas ar vardarbību vai draudiem". No minētā izriet, ka 150. pants varētu tikt piemērots homofobijas gadijumos.

Krimināllikuma 150. pants paredz atbildību par mēǵinājumu izraisīt negatīvas emocijas pret kādu cilvēku grupu, apzīmogot kā nepilnvērtīgu (Judins, 2020). Krimināltiesību literatūrā naids ir raksturots kā jūtas, kurām raksturīgs l̦aunums, nelabvēlība (pret kādu), savukārt neiecietība tiek definēta kā nepamatoti negatìva attieksme pret cilvēkiem, viṇu dzīvesveidu, uzskatiem, jūtām, paražām (Liholaja, 2018).

Krimināllikumā ir norobežotas naida runas un naida noziegumu kategorijas:

1) atbildība par naida noziegumiem un naida runu, kuras pamatā ir personas rase, nacionālā vai etniskā izcelsme, paredzēta Krimināllikuma 78. pantā;

2) atbildỉba par naida noziegumiem un naida runu, kuras pamatā ir personas reliǵiskā pārliecība, paredzēta Krimināllikuma 150. pantā.

Publiskajā telpā izplatītie aizspriedumi un stereotipi, kas aizskar cilvēku cieņu, iziet ārpus Latvijas Republikas Satversmes 100. pantā, 1950. gada 4. novembra Cilvēka tiesību un pamatbrīvību konvencijas 10. pantā un ANO 1976. gada 23. marta "Starptautiskā 
pakta par pilsoṇu un politiskajām tiesībām" 19. pantā noteiktajām tiesībām uz vārda brīvību. Kaut arī aizspriedumi un stereotipi parasti nav vērtējami kā uzskati, kas apzināti vērsti uz nacionālā, etniskā, rasu, reliǵiskā vai sociālā naida vai nesaticības izraisišanu, tie var kḷūt par motīvu šādam noziedzīgam nodarījumam, tādēḷ šādu uzskatu izplatišsana nav vēlama. Vairāki aptaujātie ir norādījuši, ka būtu lietderīgi paredzēt administratīvo atbildību par sociālai grupai piederīgo personu goda publisku aizskaršanu vai cieņas publisku pazemošanu atkarībā no šo personu dzimuma, vecuma, invaliditātes, rases, nacionālās, etniskās vai reliǵiskās piederības vai jebkuru citu pazīmju dẹl (Kamenska, Trel̦s, 2017).

Attiecībā uz dažādu aizsargāto interešu būtiskumu Eiropas Cilvēktiesību tiesa 2012. gada 9. februāra sprieduma lietā Vejdeland and others v. Sweden, iesnieguma Nr. 1813/07, 55. punktā lēma: “Tiesa uzsver, ka diskriminācija, kas balstīta uz seksuālo orientāciju, ir tikpat nopietna kā diskriminācija, kas balstīta uz rasi, izcelsmi vai ādas krāsu." Šajā lietā Eiropas Cilvēktiesību tiesa lēma, ka kriminālatbildība un piespriestais sods (naudassods un nosacìts cietumsods) par homofobiska satura skrejlapu izplatî̌šnu skolā nepārkāpj notiesāto tiesības uz vārda brīvību, ko aizsargā Eiropas Cilvēktiesību konvencijas 10. pants. Savukārt 2016. gada 29. septembra lēmumā lietā Nr. 11816003310, nosakot būtisku kaitējumu Krimināllikuma 145. pantā paredzētajā noziedzīgajā nodarỉjumā, Augstākās tiesas Krimināllietu departaments precizēja, ka "ne katrs Latvijas Republikas Satversmē garantēto tiesību aizskārums pats par sevi, bez aizskāruma izvērtējuma, atzīstams par būtisku kaitējumu likuma 23. panta izpratnē. Būtisks kaitējums nosakāms, pamatojoties uz tiesā pārbaudītiem pierādījumiem, izvērtējot interešu apdraudējuma veidu, saturu, intereses nesēja jeb personas, pret kuru vērsts apdraudējums, īpašības un attieksmi pret konkrēto interešu apdraudējumu" (Latvijas Republikas Augstākās tiesas apkopojums, 2018). Problēma saistībā ar Krimināllikuma 150. panta piemērošanu ir pantā iekḷautais "būtisks kaitējums", proti, noziedzīgie nodarỉjumi ir ar materiālu sastāvu, un nepieciešamā pazīme ir seku iestāšanās - būtiska kaitējuma nodarīšana. Homofobisku uzbrukumu vai seksuālās uzmākšanās gadījumi ir īpaši ar to, ka faktiski nevar noteikt būtiskā kaitējuma iestāšanos.

\section{Secinājumi}

Pamatojoties uz analizētā regulējuma kopumu, jāsecina, ka konkrētu valsts nostāju attiecībā uz nereǵistrēto partnerattiecību subjektu dzimuma kritērijiem nosaka un ietekmē sabiedrībā pastāvošās attieksmes, t. i., aizspriedumi, stereotipi par viendzimuma attiecībām un par ārlaulības attiecībām starp pretēja dzimuma pārstāvjiem, kuru ietekmi nosaka arī reliǵiskā piederība un paražas, kā arī subjektīvie priekšstati par sabiedrībā akceptētajām sociālām normām. Ir nepieciešams turpināt sabiedrību informēt un izglìtot, kā arī veicināt iecietību pret seksuālajām minoritātēm (un ne tikai), piemēram, par to, ka katra cilvēka pamattiesības ir brīvi izvēlēties attiecību formu ar otru personu (stāties laulībā, dzīvot partnerattiecībās u. c.). 
Homofobisku uzbrukumu vai seksuālās uzmākšanās gadījumi var izpausties gan kā fizisks aizskārums, gan vārdiski publiskās un ne tik publiskās vietās. Ja homofobisku uzbrukumu gadījumā nav bijusi fiziska saskarsme, tad atbildība par šādiem nodarỉjumiem krimināltiesību normās nav atrodama. Analizējot atbildību par huligānismu, jāsecina, ka inkriminētā noziedzīga nodarījuma izdarī̌ana publiskā vietā pati par sevi nenozīmē, ka izdarītais jākvalificē kā huligānisms, ja nevienas citas personas intereses netika aizskartas un rupja sabiedriskā miera traucēšana netika konstatēta. Lai sauktu pie atbildības homofobiska uzbrukuma vai seksuālās uzmākšanās gadỉjumā, jābūt citu personu (sabiedrības) interešu aizskārumam.

Kā vienu no diskutējamiem risinājumiem, lai sauktu pie atbildības homofobiska uzbrukuma vai seksuālās uzmākšanās gadījumā, var piedāvāt grozịjumus Administratīvās atbildības likuma 21. panta 5. punktā, kas nosaka, ka atbildību par administratīvo pārkāpumu var pastiprināt šādi apstākḷi: “5) pārkāpuma izdarīšanas motīvs ir naids pret tādām atšḳirīgām personas iezīmēm kā rase, religískā pārliecība, nacionālā piederība vai citas skaidri nosakāmas personas atšḳirīgās iezīmes". Būtiski papildināt minēto uzskaitījumu, iekḷaujot tajā seksuālo orientāciju, jo arī šāda veida pārkāpumi ir vērsti pret tādām demokrātiskā sabiedrībā īpaši aizsargājamām (partneru, arī seksuālo minoritāšu) tiesiskajām interesēm kā vienlīdzība un cilvēka cieṇa.

Būtu jāpapildina arī Administratīvo sodu likuma par pārkāpumiem pārvaldes, sabiedriskās kārtības un valsts valodas lietošanas jomā III nodaḷa "Administratīie pārkāpumi sabiedriskās kārtības jomā", iekḷaujot tajā jaunu normu - 14. pantu šādā redakcijā: "14. pants. Homofobiski uzbrukumi vai seksuālā uzmākšanās. (1) Par homofobisku uzbrukumu, ja nav iestājušās būtiskas sekas un nav izraisīti veselības traucējumi vai vispārējo darbspēju zaudējums, piemēro naudas sodu no četrdesmit divām līdz simt naudas soda vienībām. (2) Par seksuālo uzmākšanos, ja nav bijusi fiziska saskarsme un nav izraisīti veselības traucējumi vai vispārējo darbspēju zaudējums, piemēro naudas sodu no četrdesmit divām līdz simt naudas soda vienībām."

Minētais piedāvājums ir tapis tādēl, ka atbildība par sīku huligānismu, kura ir paredzēta šā likuma 11. panta pirmajā dạ̦ā, ir saistāma ar vispārpien̦emto uzvedības normu pārkāpumu. Tomēr, kā jau secināts šajā rakstā, konkrētajā gadījumā sabiedrības uzskati un priekšstati par šādām normām partneru vai seksuālo minoritāšu aizskāruma gadījumā ir visai atškirīīgi. 


\section{Partnership and Homophobia: Legal Problems in the Republic of Latvia}

\section{Abstract}

In a more global context, it is known that individuals sometimes migrate in order to escape prejudice and discrimination in their country of origin by moving to a more tolerant host country where they can engage in sexual behaviour more freely. Nevertheless, there is almost no research on the consequences of immigration for LGBT people (Carrillo, 2004). Cases of homophobic assault or sexual harassment can take form of physical abuse, verbal or public, and not just public.

The author has concluded that if there has been no physical contact in the case of homophobic attacks, no liability for such offenses can be found under criminal law. Analysing the responsibility for hooliganism, it can be concluded that the commission of a criminal offense in a public place does not in itself mean that the crime should be classified as hooliganism, and no other person's interests were harmed and no serious disturbance of public peace was found. In order to be prosecuted in the case of homophobic assault or sexual harassment, the interests of other persons (society) must be harmed.

Keywords: partnerships, same-sex marriage, marriage, homophobia.

\section{Avoti un literatūra}

1. Acosta, F. X. 1975. Etiology and Treatment of Homosexuality: A Review. Archives of Sexual Behavior. 4(1), 9-29.

2. Administratīvo sodu likums par pārkāpumiem pārvaldes, sabiedriskās kārtības un valsts valodas lietošanas jomā. Iegūts no: https://likumi.lv/ta/id/314808 [sk. 22.02.2021.].

3. ANO Vispārējā cilvēktiesību deklarācija. 1948. Iegūts no: https://www.tiesibsargs.lv/lv/pages/ tiesibu-akti/ano-dokumenti/ano-vispareja-cilvektiesibu-deklaracija [sk. 18.12.2020.].

4. Auziņa, A. 2012. Geji un kristietība. Satori. Iegūts no: http://satori.lv/raksts/4457/Anna_Auzina/ Geji_un_kristietiba\#_ftn1 [sk. 31.07.2021.].

5. Biblos. Priesteris Dionisijs Svečnikovs. Par "civillaulību”. Iegūts no: http://biblos.lv/par_civillaulibu.html [sk. 15.11.2013.].

6. Carrillo, H. 2004. Sexual migration, cross-cultural sexual encounters, and sexual health. Sexuality Research E Social Policy. 1(3), 58-70. Iegūts no: https://doi.org/10.1525/srsp.2004.1.3.58 [sk. 22.02.2021.].

7. Clink, K. 2013. GLBTQ: An Encyclopedia of Gay, Lesbian, Bisexual, Transgender and Queer Culture, Reference Reviews, Vol. 27 No. 6, pp. 21-22. https://doi.org/10.1108/RR-03-2013-0055 [sk. 22.02.20121.].

8. Council of Europe. Recommendation No. R (97)20 of the Committee of Ministers to Member States on "Hate Speech". Iegūts no: https://rm.coe.int/1680505d5b [sk. 21.12.2020.].

9. Delfi.lv. 2013. Pāvests aicina nenosodit gejus. Iegūts no: http://www.delfi.lv/news/world/other/ pavests-aicina-nenosodit-gejus.d?id=43520003\#ixzz3hwkiwkPt [sk. 06.06.2014.]. 
10. Dzērve, L. 2020. Nevajadzēja izturēties kā lesbietēm - homofobisku uzbrukumu izmeklēšana pirms astoniem gadiem un tagad. DelfiPlus. Iegūts no: https://www.delfi.lv/news/national/politics/nevajadzeja-iztureties-ka-lesbietem-homofobisku-uzbrukumu-izmeklesana-pirms-astoniem-gadiem-un-tagad.d?id=52689915 [sk. 22.02.2021.].

11. Eiropas Cilvēktiesību tiesa. 2012. gada 9. februāra spriedums lietā Vejdeland and others v. Sweden. Iegūts no: https://hudoc.echr.coe.int/eng\#\{\%22itemid\%22:[\%22001-109046\%22]\} [sk. 12.12.2020.].

12. Eiropas Parlaments. 2016. Eiropas Parlamenta rezolūcija par homofobiju Eiropā. Iegūts no: https://www.europarl.europa.eu/sides/getDoc.do?pubRef=-//EP//TEXT+MOTION+P6-RC-20060025+0+DOC+XML+V0//LV [sk. 22.02.2021.].

13. Eiropas Parlaments, 2019. Eirobarometra speciālaptauja Nr. 91.1. Aptauja tuvāk pilsoṇiem, tuvāk vēlēšanām. Iegūts no: https://www.europarl.europa.eu/at-your-service/files/be-heard/ eurobarometer/2019/closer-to-the-citizens-closer-to-the-ballot/executive-summary/lv-eurobarometer-2019-executive-summary.pdf [sk. 22.02.2021.].

14. Fuko, M. 2000. Seksualitātes vēsture. I sējums. Zinātgriba. Rīga: Zvaigzne ABC.

15. ILGA-Europe - the European Region of the International Lesbian, Gay, Bisexual, Trans and Intersex Association. Iegūts no: https://rainbow-europe.org/\#8642/0/0 [sk. 23.11.2020.].

16. Jarkina, V., Unbedahte, A. Daži aspekti par partnerattiecībām Latvijā un ārvalstīs. Latvijas Vēstnesis. 47(590). Iegūts no: http://www.juristavards.lv/?menu=DOC\&id=200766 [sk. 15.11.2013.].

17. Kamenska, A., Brands-Kehre, I. 2008. Naida noziegumi Latvijā: likumdošana un policijas prakse. Latvijas Cilvēktiesību centrs. Iegūts no: http://cilvektiesibas.org.lv/media/attachments/29/01/2012/Naida_noziegums_LAT_internetam.pdf [sk. 12.12.2020.].

18. Kamenska, A., Trẹ̦s, E. 2017. Naida noziegumi: prakse un problēmas. Nacionālais ziṇojums Latvija. Latvijas Cilvēktiesību centrs. 62-63. Iegūts no: https://www.activecitizensfund.lv/storage/ documents/naida-noziegumi-prakse-un-problemas.pdf [sk. 12.12.2020.].

19. Krastiņs, U., Liholaja, V. 2016. Krimināllikuma komentāri. Otrā daḷa. Rīga: Tiesu nama agentūra, 43.

20. Krastin̦š, U., Liholaja, V. 2018. Krimināllikuma komentāri. Otrā daḷa (IX-XVII nodaḷa). Otrais papildinātais izdevums. Rìga: Tiesu namu aǵentūra, 409.

21. Latvijas Republikas Augstākā tiesa. 2018. Apkopojums par naida runu un vārda brīvību. Iegūts no: http://webcache.googleusercontent.com/search?q=cache:RXu5wT-IjjcJ:www.at.gov.lv/files/ uploads/files/6_Judikatura/Tiesu_prakses_apkopojumi/2018/Naida\%2520runa\%2520un\%2 520varda\%2520briviba_Apkopojums_2018_22_10_2018.doc $+\& c d=1 \&$ hl $=$ lv\&ct=clnk\&gl=lv [sk. 12.12.2020.].

22. Latvijas Republikas Satversmes tiesa. 2020. gada 12. novembra spriedums lietā Nr. 2019-33-01. Iegūts no: https://www.satv.tiesa.gov.lv/wp-content/uploads/2019/12/2019-33-01_Spriedums-3. pdf [sk. 12.11.2020.].

23. Latvijas Sabiedrības Mediji. 2020. Saeima noraida pilsonu iniciatìvu par viendzimuma partnerattiecību registrēšanu. Iegūts no: https://www.lsm.lv/raksts/zinas/latvija/saeima-noraida-pilsonu-iniciativu-par-viendzimuma-partneru-attiecibu-registresanu.a379760/ [sk. 19.12.2020.].

24. Lavrikovs, L. 1999. Geju un lezbiešu tiesību stāvokḷa analīze Latvijā. Iegūts no: Geju un lezbiešu tiesību stāvokḷa analīze Latvijā | Pētījumu un publikāciju datu bāze (mk.gov.lv) [sk. 22.02.2021.].

25. Lock, J., Kleis, B. 1998. Origins of Homophobia in Males: Psychosexual Vulnerabilities and Defence Development. American Journal of Psychotherapy. 52(4), 425-436. 
26. LTV Ziṇu dienests. 01.12.2020. Viens pret vienu: Sanita Osipova. Iegūts no: https://open.spotify. com/episode/4feH7UJNcJm07vfO08rIgA [sk. 19.12.2020.].

27. Makarovs, V. 2006. Latvijas iedzīvotāju attieksme pret seksuālajām minoritātēm: dimensijas un "temperatūra". Iegūts no: http://cilvektiesibas.org.lv/site/record/docs/2012/07/13/petbalst_ strat_toler.pdf [sk. 18.12.2020.].

28. OECD. 2017. LGBTI inclusiveness. Iegūts no: http://www.oecd.org/els/soc/lgbti.htm [sk. 21.12.2020.].

29. Padomes Pamatlēmums 2008/913/TI (2008. gada 28. novembris) par krimināltiesību izmantošanu cīṇā pret noteiktiem rasisma un ksenofobijas veidiem un izpausmēm. Iegūts no: https:// eur-lex.europa.eu/legal-content/LV/TXT/?uri=celex\%3A32008F0913 [sk. 29.12.2020.].

30. Providus. 2003. Kultūru daudzveidìba un iecietība Latvijā. Dati, fakti, viedokḷi. Iegūts no: http://providus.lv/article_files/1662/original/KulturuDaudzveidiba-brosh.pdf?1332414512 [sk. 18.12.2020.].

31. Putniṇa, A., Zīverte, L. 2008. "Neredzamās" viena dzimuma partneru giimenes Latvijā. Providus. Iegūts no: http://politika.lv/article/neredzamas-viena-dzimuma-partneru-gimenes-latvija [sk. 15.11.2013.].

32. Ritter, K. Y., Terndrup, A. I. 2002. Handbook of Affirmative Psychotherapy with Lesbians and Gay Men. The Guilford Press.

33. Sheikis, S. 2014. Invasion of LGBT Lecture. 54. slaids. Iegūts no: www.rod.lv/presentations/ sodomia_lv/sodomia_lv.ppt [sk. 15.07.2015.].

34. Trel̦s, Ē. 2012. Valsts policijas darbs daudznacionālajā sabiedrībā. Rīga: P \& K, 29-68.

35. Trel̦s, E. 2019. Naida noziegumi Latvijā: kriminālatbildība un piemērotie sodi. Socrates. 1(13). Iegūts no: doi:10.25143/socr.13.2019.1.030-041 [sk. 21.12.2020.].

36. Williamson, I. R. 2000. Internalized homophobia and health issues affecting lesbians and gay men. Health Education Research. 15(1), 97-107.

37. Woods, V., Hare, B. 2010. Bonobo but not chimpanzee infants use socio-sexual contact with peers. Primates. Iegūts no: https://www.researchgate.net/publication/49654838_Bonobo_but_ not_chimpanzee_infants_use_socio-sexual_contact_with_peers [sk. 22.02.2021.].

38. Zemzars, U., Laura, J., Liholaja, V., Judins, A., Danovskis, E., Rozenbergs, J., Gribonika, Ē. 2020. Huligānisms internetā: vai vārda brīvībai ir robežas. Jurista Vārds. 45(1155). Iegūts no: https:// juristavards.lv/doc/277529-huliganisms-interneta-vai-varda-brivibai-ir-robezas/ [sk. 19.12.2020.]. 